\title{
Translation and Validation of the Indonesian Version of SaringSikap Assessment Form
}

\author{
Mohamad Ghazali Masuri¹, Nordiyana Othman'1, Gunawan Wicaksono², Khairil Anuar Md Isa' \\ ${ }^{1}$ Faculty of Health Sciene, \\ Universiti Teknologi Mara, UITM Kampus Puncak Alam 42300 Bandar Puncak Alam, Selangor, Malaysia \\ 2 Occupational Therapy Department, \\ University Indonesia - Depok, Indonesia
}

zalie222@gmail.com, diyana.hpsf@gmail.com, wicaksono_gunawan@yahoo.com, khairil_hpm@hotmail.com

Tel: +6019-6259314

\begin{abstract}
The purpose of this study was to evaluate the face and content validity of an instrument that had developed to assess the validation of the Indonesian version of the Saringan Skala Sikap Selamat@ (SaringSikap) assessment form perceived by Indonesian people. The SaringSikap is also known as Attitude towards Safe Driving Scale ( (ASDS). The content validity of the instrument was assessed by I-CVI/UA, yielding scores of .97 and .93, respectively. Findings indicated that this instrument had an excellent face and content validity and could thus be used to validate the Indonesian version of the Attitude towards Safe Driving Scale (ASDS).
\end{abstract}

Keywords: Attitude assessment; translation \& validation; road safety

eISSN: 2398-4287@ 2021. The Authors. Published for AMER ABRA cE-Bs by e-International Publishing House, Ltd., UK. This is an open access article under the CC BYNC-ND license (http://creativecommons.org/licenses/by-nc-nd/4.0). Peer-review under responsibility of AMER (Association of Malaysian Environment-Behaviour Researchers), ABRA (Association of Behavioural Researchers on Asians/Africans/Arabians) and CE-Bs (Centre for Environment-Behaviour Studies), Faculty of Architecture, Planning \& Surveying, Universiti Teknologi MARA, Malaysia.

DOI: https://doi.org/10.21834/ebpj.v6i16.2708

\subsection{Introduction}

According to the Global Status Report on Road Safety, road accident cases increased from year to year in Indonesia. According to the World Health Organization (WHO 2009), nearly 1.3 million people killed worldwide, and 50 million people injured in road traffic accidents per year. The numbers of injuries during road accidents increased more than 80 percent and the number who died in road accident reaches 120 people per day. As an occupational therapist, we were involved in educating, promote, evaluate, modify and rehabilitate people to become an Independence individual since driving can be part of the important component in the occupational performance area (Masuri, Md Isa, \& Mohd Tahir, 2012). This study discuss about translation and validation of the Indonesian version of the Attitude Towards Safe Driving Scale@ (ASDS) and aimed to translate and validate the ASDS into Indonesian version to evaluate young drivers' attitude in Indonesian population. The survey consist of two sections which is demographic data and attitude scale item which is easy and simple to administer to the general population without any special training is needed. The results could be used to convey information about the issues to the target population. Hence it is possible to plan appropriate intervention and strategies to reduce the road crashes. Therefore, from this study, the findings of this research would bring benefits to citizens and country so that the rate of incidents can be reduced, more lives saved and improve the quality of life. Based on research (Spring 2003; Rozmi 2006), they make conclusion the main causes of increasing number for road accidents is a driving attitude and it is one picture of the vulnerability stemming from human

eISSN: 2398-4287@ 2021. The Authors. Published for AMER ABRA CE-Bs by e-International Publishing House, Ltd., UK. This is an open access article under the CC BYNC-ND license (http://creativecommons.org/licenses/by-nc-nd/4.0). Peer-review under responsibility of AMER (Association of Malaysian Environment-Behaviour Researchers), ABRA (Association of Behavioural Researchers on Asians/Africans/Arabians) and cE-Bs (Centre for Environment-Behaviour Studies), Faculty of Architecture, Planning \& Surveying, Universiti Teknologi MARA, Malaysia.

DOI: https://doi.org/10.21834/ebpj.v6i16.2708 
factors Besides that Driver stress is a significant safety problem, even for professional drivers (Evans \& Johansson, 1998). Such numbers of accidents continue to occur every year and have become an alarming health problem and can have a huge effect on people's quality of life (Wan Ahmad Kamal, Masuri, Dahlan, \& Md Isa, 2015). Currently, the number of young drivers involved in a traffic accident has become pervasive. Most road traffic accidents had caused by human error. This made the error of the drivers as an important human component which needs further investigation. The rapid development related to the increase in the number of vehicles on the road could potentially increase road traffic accident possibilities. There have been several causes of an accident, either primary or secondary factors. Factors like speeding, using a cell phone and not wearing a seat belt considered to contribute to injury and fatality (Masuri, Dahlan, Danis, \& Md Isa, 2015). The number of road accidents among young adults in Indonesia is an alarming issue. Governments in Indonesia have worked very hard through relevant agencies to enforce all relevant acts relating to it. A limited number of local research and evidence conducted to date supporting driver attitudes and behaviour analysis.

\subsection{Road traffic accident among young driver's in Indonesia}

Road traffic accidents described as fatal or non-fatal injuries resulting from crashes in road traffic (Kudryavtsev 2013). The road accident may generally be described as an unexpected incident caused by a loss of driving control before the collision with an object occurs, or causing a vehicle crash causing property damage, injury to drivers, passengers and other road users or otherwise (Bergel-Hayat et al.,2013). Meanwhile, the crash is defined as a collision or incidence that may or may not cause the injury that occurs on a public road and involves at least one moving vehicle (World Health Organization, 2002). Road traffic crashes result in the deaths of approximately 1.35 million people around the world each year and leave between 20 and 50 million people with non-fatal injuries (World Health Organization, 2020).In Indonesia, road accidents are a leading cause of death. Study and statistical statistics assume that traffic accidents are the comprehension of traffic safety problems and whole transport networks. Figures describing traffic accidents in Indonesia, as in many other countries, show significantly high numbers and severity levels. These types of total are also evidence in Jakarta, the country's most densely populated city. According to Soehodho, traffic accidents in 2017 are caused mostly by three different factor forms: human factors, vehicle factors, and environmental factors (including road conditions).

\subsection{Attitude towards Safe Driving Scale (ASDS) in the previous study}

The probability of age-related road accidents has features that the letter "U." Younger drivers (under 27 years of age) and older people (over 63) have a higher accident rate while driving heavy vehicles (Duke et al., 2010). Adult drivers and young drivers tend to have a shorter first crash than seasoned young drivers using a global positioning system based on driving trend monitoring results (Ayuso et al., 2014). While the issue for older drivers is more related to erratic driving habits that can lead to crashes (Hong et al. 2016). The number of accompanying passengers and their age is also affecting accidents suffered by young car drivers (Ouimet et al., 2015). Younger adolescent passengers increase driving risk, especially when compared to solo driving or older teen drivers with fatal crash risk. This condition may be motivated by confidence bias about the driver's skills; (Zuraida et al. 2003) may feel less afraid of an accident because they consider themselves more highly skilled than their peers (White et al., 2011). Many studies have shown that attitudes rarely present the behaviour that synchronizes. Attitudes can either viewed positively or negatively. While attitude and behaviour are generally not straightforward and are sensitive depending on the social situation, it is possible to use attitude evaluation to predict future behaviour (Iversen 2004). The previous study shows that different factors such as sociodemographic issues (Al-Naggar, Bobryshev, \& Mohd Noor, 2013), socioeconomic status (Masuri, Md Isa, \& Mohd Tahir, 2012), age/gender (Scott-Parker, Watson, King, \& Hyde, 2012), level of education (Masuri, Md Isa, Mohd Tahir, et al., 2012) and living status (Al-Naggar et al., 2013) have had major effects on driving behaviour. Braitman et al. (2008) study on accident and contributing factors showed three-fourths of the teenagers involved in the crash was at fault. The crashes mainly caused by running off the road, ending another vehicle in the back, or colliding with another vehicle that had the right of way. Drivers at the age of 17 to 25 are usually called young or teen drivers. They have higher crash rates than any other age group, including minor crashes and crashes, resulting in injuries and fatalities (National Highway Traffic Safety Administration, 2001). Young drivers have high crash rates mainly due to immaturity, lack of experience and age-related lifestyles. Risky driving young inexperienced drivers significantly increase their risk of having a crash; this is especially true among men (Isler \& Starkey, 2008). In addition, a study by Ivers et al. (2009) found that risky driving behaviours were associated with a $50 \%$ increase in the risk of crashing.

\subsection{Methodology}

The research technique used is the cross-sectional study design. This design is best suited to studies aimed at finding out the driving attitudes among young adults in Indonesia. A cross-sectional study is relatively quick and easy to conduct because it does not need long follow-up periods. Figure 1 explain the process of translation and validation of this questionnaire. 


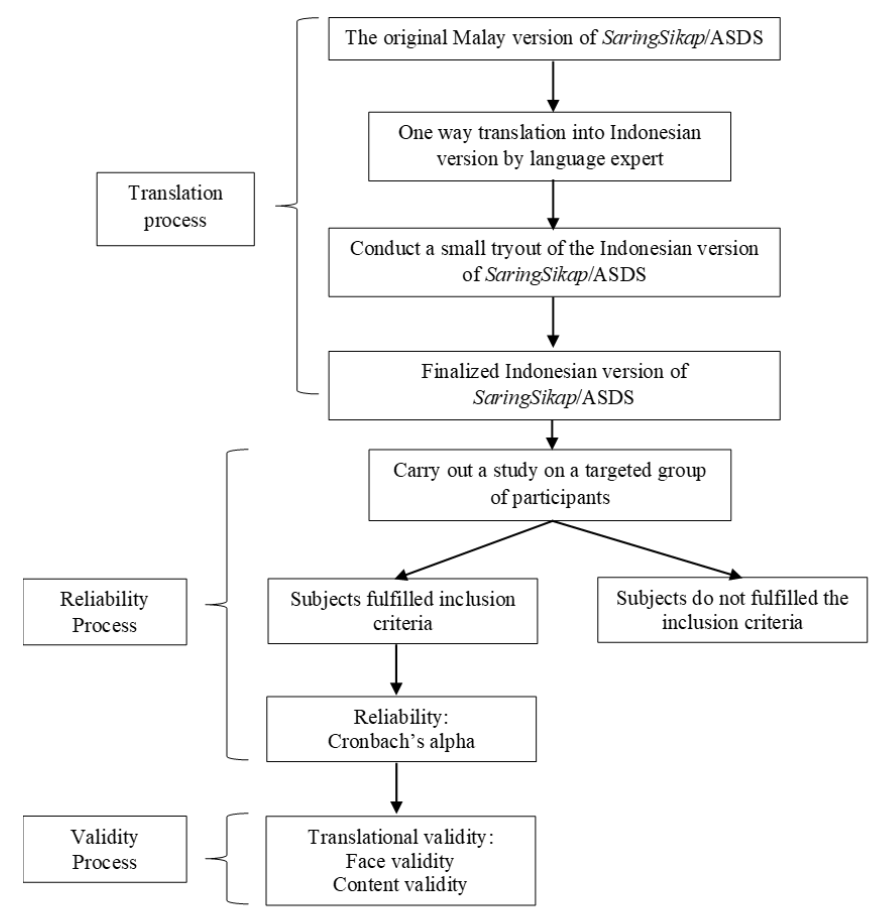

Fig. 1: Flowchart of translation and validation process of the Indonesian version of ASDS

\subsection{Translation process}

The original version of this questionnaire is in Bahasa Malaysia (Masuri et al., 2018). It is not available in Indonesian version thus, it was necessary to translate it to the Indonesia language and conducting a psychometric evaluation. The translation by an expert in University Indonesia. The ASDS was translated into Indonesia language using one-way translation. One way translation refers to using a bilingual translator who translates the instrument from the source language into the target language. It is the most frequently used method in public - health cross-cultural studies because of their simplicity, time efficiency and cost (Weeks, 2007). In placing more emphasis, Waltz et al. (2010) revealed that the advantage of one-way translation is that it is simple and inexpensive.

\subsection{Research design}

The research design used in this study is quantitative because it is about to quantify the driving attitudes among young drivers in respected countries. According to Cavana (2001) quantitative methods can be utilized to verify the hypotheses and provide strong reliability and validity. A compilation of questionnaires will be distributed among young drivers in Indonesia using the online medium (Google form).

\subsection{Validity and reliability process}

Face validity. Face validity is related to the appearance and apparent attractiveness of an instrument, which may affect respondents' instrument acceptability (Nunnally, 1994). Therefore, ten young drivers were randomly selected and completed the face validity form. At the end of the form, a space for open-ended questions was added where participants can give feedback whether sentences were clear, concise, easy to understand, and free from typographical errors. In order to examine the face validity, the dichotomous scale was used with the categorical option of "Yes" and "No" which indicate a favourable and unfavourable item respectively. Where favourable item means that the item is objectively structured and can be positively classified under the thematic category. The data collected is then analyzed using Cohen's Kappa Index (CKI) to determine the instrument's face validity. Content validity. Content validity includes the evaluation of each test item for its relevance to the intended construct, if the items are clearly and correctly worded, then there is sufficient scoring and scaling of the scale to ensure that the items of the instrument 'are representative examples of the material universe and/or the actions of the domain being discussed'. (Yassir, Mclntyre, \& Bearnm, 2016; Krikorian, 2016). A total of 10 panel experts are requested to completed content validity form via online surveys. Content validity usually undertaken by seven or more experts (DeVon et al., 2007). These experts will rate whether the items are relevant to the measured domain using a 4-point ordinal scale. The satisfactory level of content validity among experts can measured using the Content Validity Index (CVI). The appropriate CVI values for nine experts and more are at least 0.78 , according to Lynn (1986). The value of Cronbach's alpha was calculated by SPSS to measure the internal consistency of the ASDS for reliability test. A total of 127 drivers in Indonesia which is considered sufficient for successful quantitative 
analysis. This involves identifying and selecting drivers in Indonesia that are knowledgeable about or experienced with driving. In most research, a coefficient of reliability of .70 or higher is considered acceptable (Sushil \& Verma, 2010).

\subsection{Result}

Total of 44 young drivers in Indonesia who qualified in line with the inclusion criteria had voluntarily participated in the pilot test study. After completing the pilot study, the data was entered into SPSS version 17. The reliability of the Indonesia version of ASDS, as measured by internal consistency, was found to be acceptable (Cronbach's alpha $=0.76)$. As stated by George and Mallery (2003) the rules of thumb were as followed; > .9: Excellent, > .8: Good, > .7: Acceptable, > .6: Questionable, > .5: Poor, and < .5: Unacceptable. The self-compliance domain shows the highest internal consistency with the value of Chronbach's alpha .965. The Cronbach's alpha values for all the six domains shown in the table below. After completing the pilot study, the data was entered into SPSS version 17. The reliability of the Indonesian version of ASDS, as measured by internal consistency, was found to be satisfactory (Cronbach's alpha $=0.75$ )

Table 1. The Cronbach's Alpha of the Indonesian version of ASDS

\begin{tabular}{lccc}
\hline \multicolumn{1}{c}{ Domain } & Cronbach's Alpha & Cronbach's Alpha Based on Standardized Items & N of items \\
\hline Self-compliance & .965 & .965 & 13 \\
Self-confidence & .795 & .809 & 12 \\
Self-benefit & .779 & .788 & 8 \\
Self-concern & .733 & .653 & 6 \\
Self-style & .755 & .755 & 4 \\
Self-preparedness & .729 & .739 & 4 \\
\hline
\end{tabular}

The translator takes 2 weeks to fully translate the ASDS into the Indonesian language version including 21 demographic data and 46 questionnaire items. A total of 127 respondents participated in the study. The mean age was from 17 to 25 years. The majority of respondents are female were is 72 from 127 respondent. 55 respondent are male. The highest percentage of age are from group 25 years old. The lowest percentage of age are from group 18 years old. The 63 respondent are from rural and 64 respondent are from urban. From the survey 60 respondent are student and still studies and 67 respondent working and $55 \%$ are not married and $45 \%$ married. Majority of the respondent has driving license class A. $75 \%$ of the respondents, $n=99$ have received $1-3$ fines and $35 \%, n=44$ have been involved in an accident in the last 12 months. The kappa (ÿ) of the Cohen is .631. That is the proportion of agreement above and beyond the agreement of chance. The kappa (ÿ) of Cohen can range from -1 to +1. Based on the Altman guidelines (1999), and adapted from Landis \& Koch (1977), a kappa 631 represents a moderate agreement force. In addition, since $p=.000$ (which means $p$ $<.0005)$, our coefficient of kappa is statistically significantly different from zero. In an interview with one of the research team members, a group of people with expertise in driving patients (lay experts) was asked to decide on the products' driving attitude. To make some items more comprehensible, objective examples have been included in an item according to their opinions. Our instrument was prepared with seven dimensions and 46 objects for the next measures for validity and face validation process and the rest of the psychometric testing.

Table 2. Face validity of ASDS

\begin{tabular}{|c|c|c|c|c|c|}
\hline \multicolumn{6}{|c|}{ Symmetric Measures } \\
\hline & & Value & Asymp. Std. Error & Approx. Tb & Approx. Sig. \\
\hline Measure of Agreement & Kappa & .631 & .196 & 4.313 & .000 \\
\hline $\mathrm{N}$ of Valid Cases & & 46 & & & \\
\hline
\end{tabular}

\section{Content Validity}

The scale-level content validity index $(\mathrm{CVI})$ among ten experts based on the average and universal method revealed to be high with the value of S-CVI/Ave $=0.99$ and S-CVI/UA $=0.93$, respectively. These panel experts consist of 4 Road Safety Department officers and six driving instructors. They would be the best judges of the relevance of question content and construct to Indonesia's driving practice. Thus, it concludes that the Indonesia version of Attitude towards Safe Driving Scale (ASDS) has achieved a satisfactory content validity level. Sangoseni et al. (2013) stated that items were considered relevant to the theory being studied if a majority of the opinions of the panel were in agreement

\subsection{Discussion}

This paper evaluated the face and content validity for translation of the ASDS from Malay version to the Indonesian version. The goals of this study are to study and understand Indonesian driver's attitude. Results showed that the instrument's face validity was established; the questionnaire reviewed by the panel of experts indicated that it was appropriate for this study purpose. In addition, the content validity of the instrument was also evaluated. Based on the feedback received from the panel of experts, the questionnaire was revised and modified in selected parts to ensure that the degree of relevancy and representativeness of each item of the questionnaire was

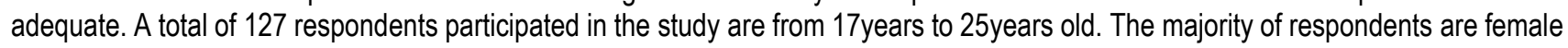


were is 72 from 127 respondent, and 55 respondents are male. This is because the participant must have a driving licence, and majority female has a driving license. The highest percentage of age are from group 25 years old. The lowest percentage of age are from group 18 years old. Cohen's kappa (ÿ) is .648. That is the proportion of agreement that is above and beyond the chance agreement. Cohen's kappa ( $\ddot{y})$ can be from -1 to +1 . A kappa of.648 is a moderate force of agreement based on the Altman guidelines (1999), and adapted from Landis \& Koch (1977). Furthermore, since $p=.000$ (which means $p<.0005)$, our kappa coefficient is statistically significantly different from zero. A group of people with expertise in driving patients (lay experts) was asked in an interview with one of the research team members to decide on the products' driving attitude. Based on the average and universal method, the scale-level content validity index (CVI) of 10 experts revealed to be high with the value of S-CVI / Ave $=0.99$ and S-CVI / UA=0.93. Such panel experts are composed of 4 officers from the Road Safety Department and six driving instructors. They would be the best judges in Indonesia on the relevance of the content of the questions and construct driving practice. Therefore, it concludes that the Indonesian version of Attitude towards Safe Driving Scale (ASDS) has achieved a satisfactory level of validity of the content. Sangoseni et al. (2013) stated that items were considered relevant to the theory under study if a majority of the panel's opinions were in agreement.

\subsection{Conclusion}

This study was created, and the proposed research for this study was conducted among university students and adults who have driving experience. Besides translation, those original Malay instruments had to be adapted cross-cultural to the Indonesian culture. When an instrument translated into another language, the translation needs to be conceptually accurate in a culturally acceptable way, rather than simply linguistically correct using a single word correspondence (WHO, 2014). In short, as evaluated using face validity and good internal consistency from the pilot study, the ASDS had good content validity. Future attitudes studies using the Indonesians version of ASDS are highly recommended to further explore the attitude of road drivers in Indonesia and other countries in the future. This new findings also supported the benefit and usability of ASDS according to previous study by Masuri, Dahlan, Md Isa, \& Hashim, (2020a \& 2020b).

\section{Acknowledgements}

The highest appreciation goes to the Ministry of Higher Education Malaysia (MoHE), Royal Malaysia Police, Research Management Centre (RMC) Universiti Teknologi MARA (UiTM), CoRe Management Science, OPERA RIG, to all panel experts as well as respondents who had participated in this study for their kind cooperation and to all staff of the Faculty of Health Sciences UiTM Puncak Alam for continuous support in staff research and development. Thank you to our local and international collaborators, Ministry of Health Malaysia, MIROS Malaysia, Tokyo University of Technology, Japan, Honam University, South Korea and Universiti Indonesia, Indonesia. This study was funded under the Fundamental Research Grant Scheme (FRGS) by MoHE - (600-IRMI/FRGS 5/3 (126/2019).

\section{Paper Contribution to Related Field of Study}

Human factors, transportation and rehabilitation.

\section{References}

Beauford, J. E., Nagashima, Y., \& Wu, M. H. (2009). Using translated instruments in research. Journal of College Teaching \& Learning (TLC), 6(5).

Bernard, H. R. (2017). Research methods in anthropology: Qualitative and quantitative approaches. Rowman \& Littlefield.

Buchanan, E. A., \& Hvizdak, E. E. (2009). Online survey tools: Ethical and methodological concerns of human research ethics committees. Journal of Empirical Research on Human Research Ethics, 4(2), 37-48.

Chavez L.M. \& Canino G. (2005). Toolkit on Translating and Adapting Instruments. Retrieved from: < http://www.hsri.org/files/uploads/publications/PN54_Translating _ and_Adapting.pdf > .

Kimberlin, C. L., \& Winterstein, A. G. (2008). Validity and reliability of measurement instruments used in research. American journal of health-system pharmacy, 65(23), 2276-2284.

Lancaster, G. A., Dodd, S., \& Williamson, P. R. (2004). Design and analysis of pilot studies: recommendations for good practice. Journal of evaluation in clinical practice, $10(2), 307-312$

Masuri, M. G., Dahlan, A., Md Isa, K. A., \& Hashim, R. (2020a). The Development and Validation of Pre-Driving Assessment: Attitude towards safe driving scale. Environment-Behaviour Proceedings Journal, 5(13), 337-342.

Masuri, M. G., Dahlan, A., Md Isa, K. A., \& Hashim, R. (2020b). The Application of HIRARC on Attitude towards Safe Driving Scale (ASDS) according to PreSiM Model. Environment-Behaviour Proceedings Journal, 5(14), 281-286.

Masuri, M. G., Dahlan, A., Danis, A., \& Isa, K. A. (2017). Attitude towards Safe Driving Scale (ASDS-46) as a Future Predictor in Determining a Young Adult Quality Of Life: Part II. Environment-Behaviour Proceedings Journal, 2(5), 363. 
Masuri, M. G., Dahlan, A., Danis, A., \& Isa, K. A. M. (2015). Public participation in shaping better road users in Malaysia. Procedia-social and behavioral sciences, 168, $341-348$.

Masuri, M. G., Dahlan, A., Danis, A., \& Isa, K. A. M. (2018). Attitude towards Safe Driving Scale (ASDS-46) as a Predictor of Young Adult Quality Of Life. Asian Journal of Quality of Life, 3(11), 11-20.

Mitra, N. K., Nagaraja, H. S., Ponnudurai, G., \& Judson, J. P. (2009). The levels of difficulty and discrimination indices in type A multiple-choice questions of pre-clinical semester 1 multidisciplinary summative tests. ASME, 3(1), 2-7.

Patton, M. Q. (2014). Qualitative research \& evaluation methods: Integrating theory and practice. Sage publications.

Sowtali, S. N., Yusoff, D. M., Harith, S., \& Mohamed, M. (2016). Translation and validation of the Malay version of the Stroke Knowledge Test. Journal of arrhythmia, 32(2), $112-118$.

Sowtali, S. N., Yusoff, D. M., Harith, S., \& Mohamed, M. (2016). Translation and validation of the Malay version of the Stroke Knowledge Test. Journal of arrhythmia, 32(2), 112-118.

Squires, A., Aiken, L. H., Van den Heede, K., Sermeus, W., Bruyneel, L., Lindqvist, R., ... \& Ensio, A. (2013). A systematic survey instrument translation process for multicountry, comparative health workforce studies. International journal of nursing studies, 50(2), 264-273.

Taber, K. S. (2018). The use of Cronbach's alpha when developing and reporting research instruments in science education. Research in Science Education, 48(6), 12731296.

\section{Appendix 1}

The Indonesia version of Saringan Skala Sikap Selamat@ (SaringSikap) assessment form Attitude towards Safe Driving Scale@ (ASDS)

\begin{tabular}{|c|c|c|}
\hline No & Malay version & Indonesian version \\
\hline Q1 & $\begin{array}{l}\text { Sikap pemandu yang tidak berhemah akan menyebabkan berlakunya } \\
\text { kemalangan. }\end{array}$ & $\begin{array}{l}\text { Pengemudi yang mempunyai sikap tidak baik akan menyebabkan } \\
\text { kecelakaan }\end{array}$ \\
\hline Q2 & $\begin{array}{l}\text { Saya adalah seorang pemandu berhemah yang tidak akan menyebabkan } \\
\text { kemalangan berlaku. }\end{array}$ & $\begin{array}{l}\text { Saya pengemudi yang bertanggung jawab dan tidak akan menyebabkan } \\
\text { kecelakaan jalan }\end{array}$ \\
\hline Q3 & Saya sentiasa mengamalkan corak pemanduan yang berhati-hati. & Saya selalu berlatih mengemudi secara hati hati \\
\hline Q4 & Saya boleh menghadapi sebarang kesan dari corak pemanduan saya. & $\begin{array}{l}\text { Saya dapat menangani efek/dampak apa pun yang disebabkan oleh cara } \\
\text { mengemudi saya }\end{array}$ \\
\hline Q5 & $\begin{array}{l}\text { Saya bersedia untuk terlibat dengan kemalangan kesan dari corak pemanduan } \\
\text { saya. }\end{array}$ & $\begin{array}{l}\text { Saya siap terlibat dalam kecelakaan di jalan karena cara mengemudi } \\
\text { saya. }\end{array}$ \\
\hline Q6 & $\begin{array}{l}\text { Saya boleh menghadapi sebarang kemungkinan dari corak pemanduan sedia } \\
\text { ada saya. }\end{array}$ & $\begin{array}{l}\text { Saya dapat menangani segala kemungkinan yang disebabkan oleh cara } \\
\text { mengemudi saya saat ini }\end{array}$ \\
\hline Q7 & $\begin{array}{l}\text { Mengubah corak pemanduan saya adalah satu halangan yang akan } \\
\text { menghadkan pergerakan saya di atas jalanraya. }\end{array}$ & $\begin{array}{l}\text { Mengubah cara mengemudi saya adalah salah satu kendala yang akan } \\
\text { membatasi gerak saya di jalan . }\end{array}$ \\
\hline Q8 & $\begin{array}{l}\text { Mengubah corak pemanduan saya adalah satu halangan walaupun ia dapat } \\
\text { mengelakkan saya dari terlibat dengan kemalangan. }\end{array}$ & $\begin{array}{l}\text { Merubah cara mengemudi saya adalah hambatan, walaupun itu akan } \\
\text { mencegah kecelakaan yang akan terjadi pada saya }\end{array}$ \\
\hline Q9 & $\begin{array}{l}\text { Cara pemanduan saya bukanlah halangan untuk kemalangan dari berlaku } \\
\text { kerana ianya adalah takdir. }\end{array}$ & Cara mengemudi saya bukan penyebab kecelakaan yang terjadi \\
\hline Q10 & Pemanduan berhemah dapat mengelakkan diri dari terlibat dengan kemalangan. & $\begin{array}{l}\text { Cara mengemudi yang baik dapat membantu mencegah kecelakaan jalan } \\
\text { raya }\end{array}$ \\
\hline Q11 & $\begin{array}{l}\text { Kemalangan tidak akan dapat dielakkan jika ada pememandu lain yang tidak } \\
\text { berhemah }\end{array}$ & $\begin{array}{l}\text { Kecelakaan tidak dapat di hindari bila ada pengemudi lain yang tidak } \\
\text { bertanggung jawab }\end{array}$ \\
\hline Q12 & Cara saya memandu boleh mengelakkan dari kemalangan berlaku. & Cara mengemudi saya saat ini menghindari saya dari kecelakaan di jalan \\
\hline Q13 & Saya mampu, untuk mengawal diri saya dari terlibat dengan kemalangan. & $\begin{array}{l}\text { Saya mampu mengendalikan diri saya sendiri agar tidak terlibat dalam } \\
\text { kecelakaan }\end{array}$ \\
\hline Q14 & Saya mampu, untuk mengawal diri saya dari melanggar peraturan jalanraya. & Saya mampu mengendalikan diri saya sendiri dari pelanggaran lalu lintas \\
\hline Q15 & $\begin{array}{l}\text { Saya mampu, untuk mengawal diri saya dari menjadi pencetus kepada } \\
\text { kemalangan. }\end{array}$ & $\begin{array}{l}\text { Saya mampu mengendalikan diri saya sendiri dari penyebab kecelakaan } \\
\text { jalan }\end{array}$ \\
\hline Q16 & Saya yakin boleh mengekalkan corak pemanduan saya yang baik. & $\begin{array}{l}\text { Saya yakin bahwa saya dapat mempertahankan cara saya mengemudi } \\
\text { dengan baik }\end{array}$ \\
\hline Q17 & Saya yakin boleh mengelakkan diri dari melakukan kesalahan jalanraya. & Saya yakin bahwa saya dapat menghindari bentuk pelanggaran lalu lintas \\
\hline Q18 & Saya yakin, saya tidak akan melanggar peraturan jalanraya. & Saya yakin bahwa saya tidak akan melakukan pelanggaran lalu lintas \\
\hline Q19 & Terlibat dengan kemalangan akan dapat menyedarkan saya tentang bahayanya. & $\begin{array}{l}\text { Terlibat dalam kecelakaan lalu lintas membuat saya sadar/mengetahui } \\
\text { bahayanya. }\end{array}$ \\
\hline Q20 & $\begin{array}{l}\text { Kemalangan akan menyedarkan saya tentang kesilapan yang berkaitan } \\
\text { dengannya. }\end{array}$ & $\begin{array}{l}\text { Kecelakaan di jalan akan membuat saya sadar/mengetahui bahwa } \\
\text { pelanggaran lalu lintas akan dapat menyebabkan hal tersebut }\end{array}$ \\
\hline Q21 & Saya tidak mempunyai sebab untuk mengubah corak pemanduan saya. & Saya tidak mempunyai alasan untuk mengubah cara mengemudi saya \\
\hline Q22 & $\begin{array}{l}\text { Kemampuan saya mengelakkan diri dari melangar kesalahan jalanraya dapat } \\
\text { mengurangkan peluang saya untuk terlibat dengan kemalangan. }\end{array}$ & $\begin{array}{l}\text { Kemampuan saya untuk menghidari pelanggaran lalu lintas dan } \\
\text { menurunkan peluang/risiko terjadinya kecelakaan lalu lintas terhadap } \\
\text { saya }\end{array}$ \\
\hline Q23 & $\begin{array}{l}\text { Kemalangan jalanraya dapat dielakkan jika masyarakat mematuhi peraturan } \\
\text { jalanraya }\end{array}$ & $\begin{array}{l}\text { Kecelakaan lalu lintas dapat dihindari jika masyarakat mematuhi } \\
\text { peraturan lalu lintas. }\end{array}$ \\
\hline Q24 & $\begin{array}{l}\text { Jika saya berjaya mengelakkan diri dari melangar kesalahan jalanraya, ia dapat } \\
\text { mengelakkan orang lain dari menjadi mangsa kemalangan. }\end{array}$ & $\begin{array}{l}\text { Jika saya mampu menghindari diri saya sendiri dari pelanggaran lalu } \\
\text { lintas, maka akan membantu orang lain menjadi korban kecelakaan lalu } \\
\text { lintas }\end{array}$ \\
\hline
\end{tabular}




\begin{tabular}{|c|c|c|}
\hline Q25 & Ketika memandu, saya sentiasa mematuhi peraturan jalanraya. & Saya selalu mengikuti peraturan lalu lintas saat saya mengemudi \\
\hline Q26 & Mematuhi peraturan jalanraya ketika memandu, bukanlah keperluan saya. & Mematuhi peraturan lalu lintas saat mengemudi, bukan prioritas saya \\
\hline Q27 & Saya benar-benar memahami peraturan-peraturan jalanraya di Malaysia. & Saya sangat mengerti peraturan lalu lintas di Indonesia \\
\hline Q28 & $\begin{array}{l}\text { Saya tidak perlu untuk memahami buku peraturan jalanraya untuk membolehkan } \\
\text { saya memandu. }\end{array}$ & $\begin{array}{l}\text { aya tidak perlu mengerti/memahami buku peraturan lalu lintas untuk } \\
\text { mengemudi }\end{array}$ \\
\hline Q29 & $\begin{array}{l}\text { Ketika memandu, saya tidak mempunyai sebarang niat untuk melakukan } \\
\text { sebarang kesalahan jalanraya. }\end{array}$ & $\begin{array}{l}\text { Saya tidak ingin/tidak ada niat untuk melakukan pelanggaran lalu lintas } \\
\text { saat mengemudi }\end{array}$ \\
\hline Q30 & $\begin{array}{l}\text { Saya mempunyai niat untuk melanggar peraturan jalanraya dalam jangkamasa } \\
12 \text { bulan ini. }\end{array}$ & $\begin{array}{l}\text { Saya ingin/ada niat untuk melakukan pelanggaran lalu lintas dalam waktu } \\
12 \text { bulan ini }\end{array}$ \\
\hline Q31 & $\begin{array}{l}\text { Ketika memandu, saya tidak akan melanggar peraturan jalanraya walaupun ada } \\
\text { peluang untuk berbuat demikian. }\end{array}$ & $\begin{array}{l}\text { Saya tidak akan melakukan pelanggaran lalu lintas saat mengemudi } \\
\text { meskipun saya memiliki kesempatan untuk melakukannya. }\end{array}$ \\
\hline Q32 & $\begin{array}{l}\text { Saya hanya akan melanggar peraturan jalanraya sekiranya saya mempunyai } \\
\text { peluang untuk berbuat demikian. }\end{array}$ & $\begin{array}{l}\text { Saya hanya akan melakukan pelanggaran lalu lintas jika saya memiliki } \\
\text { kesempatan untuk melakukannya }\end{array}$ \\
\hline Q33 & $\begin{array}{l}\text { Ketika memandu, saya tidak akan melanggar peraturan walaupun mempunyai } \\
\text { ruang untuk berbuat demikian. }\end{array}$ & $\begin{array}{l}\text { Saya tidak akan melakukan pelanggaran lalu lintas meskipun saya } \\
\text { memiliki kesempatan untuk melakukannya. }\end{array}$ \\
\hline Q34 & $\begin{array}{l}\text { Saya akan melanggar peraturan sekiranya saya melihat ruang untuk berbuat } \\
\text { demikian. }\end{array}$ & $\begin{array}{l}\text { Saya hanya akan melakukan pelanggaran lalu lintas jika saya memiliki } \\
\text { kesempatan untuk melakukannya. }\end{array}$ \\
\hline Q35 & $\begin{array}{l}\text { Banyak peluang untuk melanggar peraturan jalanraya di Malaysia, tetapi saya } \\
\text { tetap mengamalkan corak pemanduan yang berhemah. }\end{array}$ & $\begin{array}{l}\text { Ada banyak kesempatan untuk melakukan pelanggaran lalu lintas di } \\
\text { Indonesia, tetapi saya akan selalu melakukan cara mengemudi dengan } \\
\text { baik. }\end{array}$ \\
\hline Q36 & $\begin{array}{l}\text { Banyak ruang untuk melanggar peraturan jalanraya di Malaysia, tetapi saya } \\
\text { tetap mengamalkan corak pemanduan yang berhemah. }\end{array}$ & $\begin{array}{l}\text { Ada banyak kesempatan untuk melakukan pelanggaran lalu lintas di } \\
\text { Indonesia, tetapi saya akan selalu melakukan cara mengemudi dengan } \\
\text { baik. }\end{array}$ \\
\hline Q37 & $\begin{array}{l}\text { Saya akan terlepas dari hukuman atas kesalahan jalanraya yang saya lakukan } \\
\text { disebabkan oleh adanya ruang yang banyak. }\end{array}$ & $\begin{array}{l}\text { Pelanggaran lalu lintas saya lakukan tidak akan dihukum karena banyak } \\
\text { kesempatan untuk melakukannya. }\end{array}$ \\
\hline Q38 & $\begin{array}{l}\text { Saya akan terlepas dari hukuman atas kesalahan jalanraya yang saya lakukan } \\
\text { disebabkan oleh adanya peluang yang banyak. }\end{array}$ & $\begin{array}{l}\text { Pelanggaran lalu lintas saya lakukan tidak akan dihukum karena banyak } \\
\text { peluang untuk melakukannya. }\end{array}$ \\
\hline Q39 & $\begin{array}{l}\text { Saya rasa yakin untuk melanggar peraturan kerana terdapat ruang untuk } \\
\text { melakukannya. }\end{array}$ & $\begin{array}{l}\text { Saya merasa percaya diri untuk melakukan pelanggaran lalu lintas karena } \\
\text { ada peluang untuk melakukannya. }\end{array}$ \\
\hline Q40 & $\begin{array}{l}\text { Saya rasa selamat untuk melanggar peraturan kerana terdapat ruang untuk } \\
\text { melakukannya. }\end{array}$ & $\begin{array}{l}\text { Saya merasa aman untuk melakukan pelanggaran lalu lintas karena ada } \\
\text { peluang untuk melakukannya. }\end{array}$ \\
\hline Q41 & $\begin{array}{l}\text { Saya rasa yakin untuk melanggar peraturan kerana terdapat peluang untuk } \\
\text { melakukannya. }\end{array}$ & $\begin{array}{l}\text { Saya merasa percaya diri untuk melakukan pelanggaran lalu lintas karena } \\
\text { ada kesempatan untuk melakukannya. }\end{array}$ \\
\hline Q42 & $\begin{array}{l}\text { Saya rasa selamat untuk melanggar peraturan kerana terdapat peluang untuk } \\
\text { melakukannya. }\end{array}$ & $\begin{array}{l}\text { Saya merasa aman untuk melakukan pelanggaran lalu lintas karena ada } \\
\text { kesempatan untuk melakukannya. }\end{array}$ \\
\hline Q43 & $\begin{array}{l}\text { Saya rasa bersalah untuk melanggar peraturan walaupun ada ruang untuk } \\
\text { melakukannya. }\end{array}$ & $\begin{array}{l}\text { Saya merasa bersalah melakukan pelanggaran lalu lintas meskipun ada } \\
\text { peluang untuk melakukannya }\end{array}$ \\
\hline Q44 & $\begin{array}{l}\text { Saya rasa bersalah untuk melanggar peraturan walaupun ada peluang untuk } \\
\text { melakukannya. }\end{array}$ & $\begin{array}{l}\text { Saya merasa bersalah melakukan pelanggaran lalu lintas meskipun ada } \\
\text { kesempatan untuk melakukannya. }\end{array}$ \\
\hline Q45 & $\begin{array}{l}\text { Saya tidak rasa bersalah untuk melanggar peraturan kerana semua orang akan } \\
\text { menggunakan ruang yang ada untuk melakukannya. }\end{array}$ & $\begin{array}{l}\text { Saya tidak merasa bersalah melakukan pelanggaran lalu lintas karena } \\
\text { semua orang akan menggunakan peluang untuk melakukannya. }\end{array}$ \\
\hline Q46 & $\begin{array}{l}\text { Saya tidak rasa bersalah untuk melanggar peraturan kerana semua orang akan } \\
\text { menggunakan peluang yang ada untuk melakukannya. }\end{array}$ & $\begin{array}{l}\text { Saya tidak merasa bersalah melakukan pelanggaran lalu lintas karena } \\
\text { semua orang akan menggunakan kesempatan untuk melakukannya.. }\end{array}$ \\
\hline
\end{tabular}

